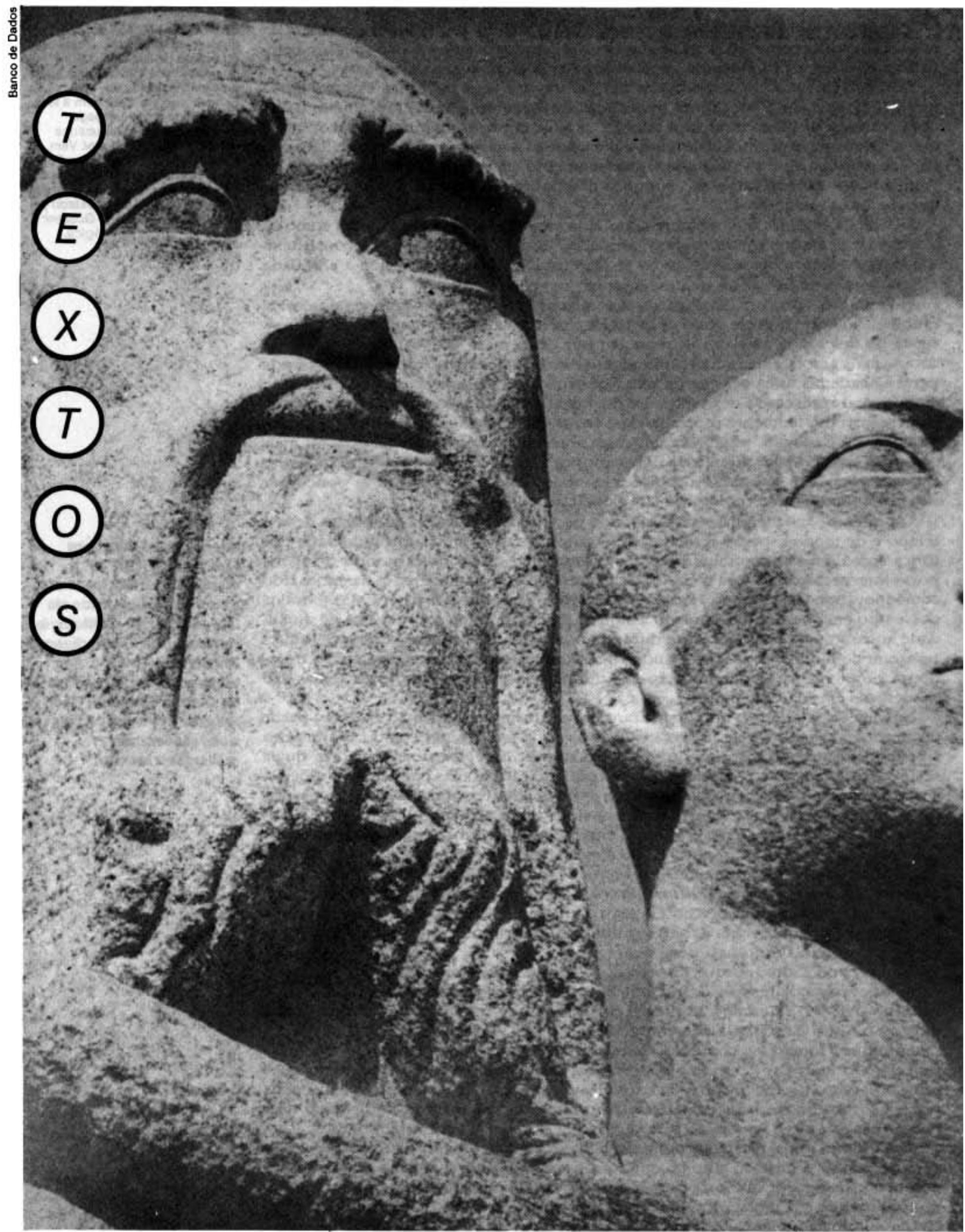




\section{Ufanismo paulista:}

\section{vicissitudes de um imaginário}

MARIA ISAURA PEREIRA DE QUEIROZ

Cada coletividade tende a ter seus símbolos próprios, dotados de um significado específico, com a função de perpetuar determinados valores. Ser paulista, manifestaçấo de uma coletividade geograficamente localizada, se exprime através de uma figura mítica, a do bandeirante; feitos do passado definem a este, quando conquistou para a Coroa portuguesa o imenso interior brasileiro, caracterizando-se entâo pela audácia, pelo desejo imoderado de conquista, pelo sentimento de independéncia, pela vocaçáo de mando, pela lealdade - "raça de gigantes" disse já um historiador (1). Tem-se a impressáo de que a imagem sempre existiu, desde os antigos tempos em que as bandeiras percorriam os sertốes em busca do ouro.

Descobrir que tal na verdade năo ocorreu e que, pelo contrário, seu aparecimento está perfeitamente localizado năo só no espaço mas também no tempo constitui uma primeira surpresa. A consulta aos dicionários da lingua portuguesa traz um primeiro esclarecimento a respeito. Verifica-se, assim, que no Diccionario da Lingua Portugueza, publicado em 1802 por Moraes e Silva (1757-1824), o termo nấo existe, mas a palavra "bandeira" está devidamente registrada: "Bandeiras, no Brasil e Minas (sie), săo associaçóes de homens que văo pelos Sertốes debaixo de um cabeça, descobrir terras mineiras. Dantes chamavăo assim os que iâo descobrir Indios gentios e conduzi-los, ou cativá-los, resgatá-los" (2). O autor indica a fonte de sua informaçăo: "Vieira, Cartas" ; contemporaneo das bandeiras, o Pe. Antonio Vicira (1608-97) utilizava pois a đenominaçăo nas tåo famosas Cartas.

Muito mais tarde, Antônio Cândido de Figueiredo (1846-1925), cm seu Novo Dícionário da Lingua Portuguesa, ediçăo de 1913, registra já o conceito de bandeirante sob a forma seguinte: "Bandeirante: indivi- 
MARIA ISAURA PEREIRA DE QUEIROZ ó pesquisadora do Centro de Estudos Rurais o

Urbanos do Departamento do Sociologia da FFLCH-USP.

Este texto foi apresentado ao $46^{\circ}$ Congresso internacional de Americanistas (Amstordá, Holanda - 4 a 8 de jutho de 1988) em mesa-rodonda com o tema "Regionalismo o Identidado Nacional".

1 Alfredo Ellis Jr. publicou sou livro Raca de Gigartas em 1926.

2 Moraes e Silva, Diccionario da Lingua Portugueza, 2 vols., s/d, porobm com a seguinte nota, ao firm da - Epitome da Grammatica Por. tugueza" que antecede o dicionario: - Acabou-se esta Epitome da Grammatica Portuguoza no Engenho novo da Moribeca om Pernambuco, ace 15 de Julho de 1802": a ediçáco consultada b. pois, anterior a ossa data Sabe-so que a primeira ediçáo do dicionario fol publicada om Lisboa, om 1789, a que se seguiram muitas outras.

3 António Cêndido de Figueiredo. Nowo Diciondirio da Lingua Portu. guosa Livraria Classica Ed. nova ediçáo, 1913. O autor, portugubs. declara na introduçho ter incluido mais de sete mil brasiloirismos que " nunca haviam entrado em diccionarios de lingua portugueza" atb entấ, pois, como seu if. vo se destinava " a todos os po. vos que falarn portuguez, náo po. de prescindir dos termos brasili. cos..." (p. D).

4 Carlos Teschauer, Novo Diciondirio Nacional, Porto Alegre (RS), 20 ad. 1928. Carlos Teschavor. josuita, veio para o Brasil em 1830. foxou-se no Rio Grande do Sul: albm de sua tarefa apostólica, publicou muitas obras sobre a regiâo om que habitava.

5 Laudelino de Oliveira Freire, Gran do - Novissimo Diciondrio da Lin gua Portuguosa 5 vols., 1938. O autor, filblogo e onsaista, membro da Academia Brasileira de Letras, dobrou inúmeras obras om que demonstrou seus conhecimentos do lingua e literatura nacionais.

6 Aurblio Buarque de Holanda Fer. roira, Pequeno Dicionário Brasilot. ro da Lingua Portuguesa. Rio de Janeiro, Ed. Civilizaçabo Brasileira, 100 ed. 1960.

7 Katia Maria Abud, O Sangue Inthmorato as Nobilissimas Tradi. cóos: a Construçáo do um Simbolo Paulista, $O$ Bandeirarta. Tese de Doutoramento, Departamento de História, Faculdade de Filosofia. Lotras o Ciências Humanas, Universidade de Sảo Paulo, 1986. viduo que, no Brasil, faz parte dos bandos, destinados a explorar os sertōes, atacar selvagens, etc." (3). O substantivo surge diretamente ligado a realidade, sem nada que possa sugerir alguma qualidade simbolica. Em obra exclusivamente brasileira e mais recente, o Novo Dicionario Nacional, publicada em 1928 e da autoria de Carlos Teschauer S. J. (1851-1930), bandeirante e ainda somente "o sujeito (sic) que faz parte de uma expedição chamada bandeira" (4). Jesuíta alemão radicado no Rio Grande do Sul desde fins do séc. XIX, Carlos Teschauer elaborou seu livro a partir dos vocábulos que recolheu durante sua vida, na regiăo em que habitava.

Laudelino de Oliveira Freire (1873-1937), no monumental Grande e Novfssimo Dictondirto da Lfingua Portuguesa, publicado apos sua morte, já refere dois conceitos de bandeirante: o de membro de uma bandeira que saía em busca das minas, e o de sinónimo de paulista, isto $\epsilon$, natural de S. Paulo (5). O mesmo é encontrado no Pequeno Dicionarto Brasiletro da Lingua Portuguesa, de Aurélio Buarque de Holanda Ferreira (1910-89). Nele os significados são os seguintes: "Bandeirante: individuo pertencente a uma bandelra ou associaçăo destinada a escravizar índios ou descobrir minas". Mas além do substantivo há também o adjetivo, como em Laudelino Freire: "Bandeirante: o natural de S. Paulo; paulista" (6). A edição citada e de 1960.

Nos dois últimos dicionários, o substantivo designa simplesmente um fato concreto - o pertencer a coletividade que se entrega a uma forma determinada de atividade. Aliás, o substantivo já existia no dicionário do portugués Cándido de Figueiredo, o que demonstra que no início do sec. XX ele estava plenamente admitido na linguagem daquém e dalém mar. No entanto o adjetivo, sinônimo de " paulista", é encontrado posteriormente e $\mathrm{cm}$ dicionários brasileiros. Pode-se razoavelmente supor que o termo "bandeirante", substantivo designando simplesmente quem participa de uma bandeira, teria aparecido em fins do séc. XIX, sendo que o adjetivo seria mais recente, datando do início do séc. XX.

Todo substantivo designa algo que existe materialmente e nessa constatação se esgota o seu sentido. $O$ adjetivo, por sua vez, identifica alguém ou alguma coisa por meio de características que the sấo peculiares. $\mathrm{O}$ adjetivo "bandeirante" se originou do substantivo, que the foi anterior. Sinonimo de paulista, liga esta designaçăo ao substantivo, isto $k$, ao fato histórico das bandeiras. Nesta ligaçăo se vislumbra toda uma evocação de um passado que se associa a determinados individuos, um significado histórico; se paultsta tem uma base geográfica, bandetrante tem como base uma tradição; e quem diz tradiçắo não diz somente outros tempos, mas também crenças, pensamentos, sentimentos, aspiraçōes que perpassam as geraçōes como legados permanentes, estabelecendo entre elas como que uma comunhão espiritual. O adjetivo "bandeirante" se encontra, pois, pleno de um sentido simbólico.

O pequeno passeio efetuado pelos dicionários indicou que o termo "bandeirante" ¿ datado, não aparecendo, seja como substantivo, seja como ađjetivo, senão em fins do séc. XIX; no entanto, o termo bandeira se forjou no séc. XVII muito provavelmente, e permaneceu com seu sentido de origem até os dias atuais. Uma indagação voltada para o passado desvendaria sem dúvida o momento em que os significados "paulista" e "bandeirante" se associaram como sinônimos, veiculando uma mensagem específica.

Atraves de investigaçăo em documentos históricos, Katia Maria Abud verificou que a primeira ligaçăo com as bandeiras se efetuara por intermédio do termo Paulista (7). Os dois historiadores mais antigos que estudaram as bandeiras foram, no séc. XVIII, Pedro Taques de Almeida Paes Leme (1714-77) (8) e Frei Gaspar da Madre de Deus (1714-1800) (9). Pela primeira vez foi traçada a imagem do sertanista desbravador, indômito, cheio de iniciativas, conquistador e rebelde. Tais ingredientes que indicam a formação de uma imagem lendária estavam presentes nas obras dos dois historiadores citados, definindo o nome "paulista" ; o termo "bandeirante" năo existia ainda.

Aliás, no poema "Vila Rica", de Claudio Manoel da Costa (1729-89), composto entre 1769 e 1773, o termo se encontra presente com as mesmas qualificaçôes:

" Vê os Pires, Camargos e Pedrosos, Alvarengas, Godóis, Cabrais, Cardosos. Lemos, Toledos, Pais, Guerras, Furtados, e os outros que, herois assinalados 
A nítida louvação, o claro engrandecimento estavam a indicar que se tratava de uma raça especial, com predicados fora do comum; o termo traçava uma linha clara de demarcạ̧ăo entre os que eram a ela pertencentes e os que náo podiam nela se incluir. Ao dar a sua obra o título de Nobiliarquia Paulista, o historiador Pedro Taques reforçou mais as barreiras, pois o orgulho de casta $e$ o colorido que a distingue; so tratou dos bomens bons, isto é, dos integrantes da camada superior, cujo sangue limpo e profissôes dignas lhes permitiam aspirar ao cargo de vereador.

Frei Gaspar da Madre de Deus, no entanto, alargou o conceito, englobando nele tambèm os oriundos da larga miscigenação com indígenas que ocorrera na então capitania. Para ele, as qualidades do paulista provinham de sua condição de mameluco; a independência do indígena, associando-se à eficiência c domínio de técnicas modernas do portugues, dera $\mathrm{em}$ resultado indivíduos certamente insolentes e com algo de rebeldes, porem altivos, corajosos, cheios de iniciativa e de persistência em suas atividades, o que os levara a tantos feitos notáveis.

Em ambos os historiadores, apesar dos pontos de vista diferentes que defendem convictos, registrava-se o louvor aos antigos povoadores da capitania, aos valorosos sertanistas que se embrenharam nas florestas alargando as fronteiras coloniais; tais qualidades justificavam plenamente seu direito, e o direito de seus descendentes, de ocuparem posiçăo de mando na capitania. Ao mesmo tempo os autores davam corpo a uma legenda heróica, a qual fortaleceria a coesão e solidariedade internas das grandes familias locais. Num período da historia paulista em que as guerras entre parentelas cram freqüentes e mortíferas, nâo era demais que se buscasse um meio de fortificar laços que as aproximassem, gerando a harmonia (11).

Embora tal circunstância possa parecer suficiente para explicar o aparecimento de um símbolo, Katia Maria Abud mostra outras ainda, talvez mesmo mais pertinentes. A exploração do ouro nas minas começara a declinar em 1763; o apresamento de índios nâo se mostrava mais rentável, ao contrário do que acontecera em tempos anteriores. A decadência econômica rondava as famílias paulistas, que se viam na contingência de apelar para novas atividades que viessem revigorar seus recursos.

A localização privilegiada da vila de São Paulo que, com as entradas e bandeiras, se tornara importante fulcro de comunicaçōes entre, de um lado, as capitanias do Sul c, de outro lado, as capitanias em que a mineração se efetuava, isto é, Minas Gerais, Goiás, Mato Grosso, abria novas perspectivas ligadas à exploração do comércio de gado, de muares, de gêneros alimentícios, de mercadorias variadas. Admitia-se agora plenamente que os comerciantes se incluíssem entre os bomens bons e portanto pudessem aceder à direção da vila através da Câmara; esta não ficava mais reservada exclusivamente a fazendeiros e sertanistas (12).

Sob o governo de Morgado de Mateus, de 1765 a 1776, operou-se um reerguimento local por intermédio do comércio; mas ao mesmo tempo o desenvolvimento económico atraiu inúmeros forasteiros (portugueses, espanhóis) que vinham tentar fortuna numa regiáo que se apresentava tâo propícia. Os louvores aos pau. listas, na segunda metade do sec. XVIII, a parecem como uma reação dos autóctones. ameaçados $\mathrm{cm}$ sua riqueza, $\mathrm{cm}$ sua supremacia, $\mathrm{em}$ sua hegemonia pelos recém-vindos, que thes faziam concorrência em suas posiçōes socioeconômicas, mas também e principalmente no governo das Cámaras. O desejo de opor barreiras às ambiçôes dos forastciros se refletia, pois, na poesia de Claudio Manoel da Costa, na exaltaçăo do mameluco sertanista por Frei Gaspar da Madre de Deus, na glorificặa dos veIhos troncos paulistas por Pedro Taques - estes dois últimos sendo rebentos de antigas famílias locais (13).

Mas a separação entre paulistas e estrangeiros durou pouco; o intercasamento de filhas de fazendeiros $\mathrm{e}$ individuos recém-chegados agiu como um poderoso elemento de aproximação que integrou forasteiros nos troncos existentes e lhes deu tambem foros de paulistas. O ufanismo reapareceu por volta de 1870 , com as mesmas qualidades com que os primeiros historiadores o haviam burilado. No entanto, nảo se voltava mais para o passado exclusivamente; encontrava-se firmemente im. plantado no presente, com base no fulgurante desenvolvimento económico que se havia operado na segunda metade do séc. XIX em terras que os fazendeiros desbravavam, numa demonstração de que eram lídimos continuadores dos corajosos ser.
B Pedro Taques de Almeida Paes Leme. Nobillarquia Paulistana. Gonoalogia das Principais Famf. lias de S. Paulo foi um dos traba. thos deste autor, considerado por muitos como o primoiro historia. dor paulista. Esta obra, além de outras, se oncontra reproduzida na Revista do Instituto Histórico e Geográfico Brasiloiro a também toi reeditada por Alonso d' E. Tau. nay, s/d.

9 Frei Caspar da Madre de Deus. Momónia para a Mistoria da Capi. tania de S. Paulo, Lisboa, 10 od., 1797. Este beneditino nascido em Santos dedicou.eo aos ostudos de historia do sua capitania orn sua cidado natal, para onde so rotirou depois de tet teorganizado, na ci. dade do Plo de Janeiro, a ordem na qual ora abado.

10 Citado em Abud, 1986. p. 13.

11 Ver a descricho dostas lutas em: L A Costa Pinto. Lutas de Familias no Brasil, Sáo Paulo, Cia Editora NacionaVINLIMEC. $2^{\circ}$ od. 1980.

12 Vor Abud, 1986, pp. 63 a 68.

13 Ambos eram paulistas o estavam muto preocupados ern resguar. dar, como so diria hoje, a memoria de sous maiores. Abud, p. 86. 
14 A andliso dosso periodo mostra de maneira muito clara o sentimento de injustica que reinava ontre os grandes fazendeiros do ceste pau. lista, e que os levou à fundaçáo do Partido Republicano Paulista Ver Maria lsaura Pereira de Oueiroz. $O$ Mandonismo Local na Vida Politica Brasiloira - Outros Ensaios, Silo Paulo, Ed. Ala Ómega, 1976. Ver tamborn, da mosma autora. - Um Republicano Paulista do SAC. XDX: - Fazendeiro Manoel Elpidio" in Ciéncia - Culara vol. $34, n^{\circ} 8$, aposto do 1982.

15 Aberto Salles, A Patria Paulista. Campinas. Typ. a vapor da Gazeta do Campinas, 1887, pp. 115-6. lf. mbo de Campos Sallos, formado om Diroito orn 1882, este autor debrou um precioso livro om que. alem de fornecer dados estatisti. $\infty$ interessantes, registra um ufanismo paulista na mesma linha de Podro Taques - Froi Caspar da Madre de Dous.

16 Idem, ibidem, p. 149.

17 Ver Abud, 1986, p. 13

18 A decada de 20 deste seculo tam bom 20 distinguiu no carnpo da historia Altredo Ellis Jt, publicou $O$ Bandeirismo o o Recuo do Morr. diano (1924) e, a soguir, Raça de Gigantes (1926), estudos sobre bandeiras - sortanistas. Alonso d' E. Taunay iniciou a publicaçáo de sua monumental Histbria Geral das Bandeiras Paulistas, ern onze volumes, que so estendeu de 1924 a 1950. Finalmente, Josb de Alchintara Machado voio a público com um trabalho extromamente original, construldo a partir da andliso do $\mathbf{4 5 0}$ testamentos 0 in. ventários dos scs. XVII o XVIII, reconstituindo a vida cotidiana dos sertanistas: Vida o Morto do Ban dairarta. 1926.

19 Na década de 20, o Roi do Calé, isto 6. o major cafoicultor paulista. chamava-so Coremia Lunardelli; no âmbito industrial, italianos como o Conde Mattarazzo a o Conde Crespi davam novo vigor a es. to sotor da oconomia. Entre os jovens intolectuais da Sornana de Ante Moderna incluiam-so nomes como os do Anita Malfatti na pintura Monotei Del Picchia na literatura 0 aflunco do imigrantes a capital paulista fora onorme durante as primoiras obcadas do sifc. $X X$; ontro 1908 - 1922. por exemplo. 340.000 imigrantes haviam chegado ao porto de Santos, 0 deles $80 \%$ numaram diretamente para a capital paulistana; ora, em 1900 . esta contava aponas 239.800 habitantos. Podo-so imaginat o abalo causado por tal invasbo macica de alienipenas o as consequências que traria inclusive a menta. lidade autdctone. Para dados sobre os imigrantes, ver IBGE - Reportorio Estatistico do Brasil - Quadros Retrospoctivos, Rio de Janeiro, IBGE, Śbries Estatisticas Rotros. pectivas, vol. 1, 1986 tanistas: abriam novas terras a lavoura, utilizavam novas técnicas no trato das culturas e nos meios de comunicação, lançavam-se a novos empreendimentos, numa demonstração de audácia e de visão.

Agora, porem, a figura mítica do paulista não era traçada a partir do passado; tratava-se de provar de maneira cientifica, com base em dados estatísticos que refletissem a operosidade e o arrojo dele no mundo dos negócios, mostrando que nada ficava a dever aos antepassados. Além do passado e do presente, a imagem encerrava tambèm uma projeçẫo para o futuro; a Província de São Paulo não poderia dar de si tudo quanto se esperava enquanto se mantivesse atrelada a regiōes incultas, ou atrasadas, sendo indispensável, para o seu pleno desenvolvimento, que se separasse destas. A pregação republicana, fruto do enriquecimento dos fazendeiros do chamado oeste paulista, que encerrava como uma das metas principais o ideal de uma federaçáo nacional, chegou nalguns de seus proceres até os extremos do separatismo (14).

O melhor exemplo destes foi sem dúvida Alberto Salles (1860?-1910), que difundiu tais idéias em seus escritos, querendo provar, através de raciocínios esteiados em dados estatísticos, a viabilidade de uma Săo Paulo independente. Descrevendo em 1887 "o espantoso desenvolvimento material" de sua província, afirmava: "As nossas indústrias, conquanto ainda novas, têm tomado enorme incremento e já văo, até certo ponto, se transformando em centros poderosos de atraçăo para o capital, que, de dia em dia, se acumula e procura meios seguros de aplicaçăo" (15). O crescimento demográfico năo menos notório era alimentado por correntes ininterruptas de imigrantes, subvencionadas umas, espontâneas outras, que traziam a regiăo os braços indispensáveis para o trabalho.

Ao chamar a atenção para o rápido desenvolvimento da província, apesar de todos os empecilhos colocados pela forte centralização do governo imperial, o autor tem expressठ̌es que, sob nova forma, espelham o ufanismo: "Uma provincia que realisa prodigios desta ordem, ainda maltratada pela administraçăo central, e que attesta de um modo tão positivo a sua riqueza, $€$ porque tem dentro de si mesma um grande reservatorio de forças progressivas (sic) que, a despeito de quantos obstaculos possam apparecer, tendem necessariamente a manifestar-se. Náo é certamente um povo vulgar aquelle que faz milagres desta natureza" (16)

O grande sentimento de injustiça e de impoténcia por parte dos fazendeiros do oeste paulista, que entăo náo participavam do governo, foi propício para a eclosăo do movimento separatista e para a nova glorificaçăo da figura do paulista; viam a política imperial dominada por representantes do Nordeste e do Vale do Paraíba, regiōes cuja economia declinava. As iniciativas que iam sendo tomadas pelo governo eram, em sua maioria, pouco adequadas às zonas novas que se abriam ao cultivo do cafe, e nas quais floresceu o Partido Republicano Paulista. Não aparecem nos escritos separatistas mençōes diretas a epopéia das bandeiras, mas avulta uma imagem do paulista muito próxima daquela que fora cunhada em fins do sec. XVIII. No entanto, o separatismo ficou restrito somente a um pequeno punhado de republicanos; não vingou. A idéia de federaçăo, essa sim, ganhou corpo e manteve-se como uma das reivindicações mestras do novo partido.

As bandeiras tornaram a atrair a atençắo dos estudiosos nas primeiras decadas do sec. XX. Voltando agora de novo $d$ tese de Katia Maria Abud, teria sido este o pe. ríodo " em que mais obras sobre as bandeiras foram escritas, e no qual a imagem dos bandeirantes tomou seus contornos mais nítidos" (17). Os autores relevantes foram Jose Alcântara Machado de Oliveira (1875-1941), Affonso d'E. Taunay (1875. 1941) e Alfredo Ellis Jr. (1896-1974), entre vários outros. Por nascimento ou aliança, pertenciam todos eles a velhas famílias paulistas, e seus trabalhos manifestam, explicita ou implicitamente, claro orgulho de linhagem (18).

As obras năo tinham, porém, finalidades laudatórias exclusivamente; pelo contrário, os autores se empenhavam com afinco em desvendar a verdade bistórica $a$ respeito dos sertanistas, buscando para tanto a mais farta documentaçăo possível; $e$ entre os documentos estavam os estudos de Pedro Taques e de Frei Gaspar da Madre de Deus. Estes últimos nāo parecem ter sido utilizados somente como fontes, mas também como inspiradores da imagem que se delineia nos trabalhos dos continua. dores. Como eles, os historiadores do sec. XX proclamaram a importáncia e o valor dos filbos da terra, e demonstravam que o pioneirismo, o espírito de iniciativa, a bravura do fazendeiro cafeicultor, desbravando as matas para a nova cultura, im. plantando estradas de ferro, buscando nova mão-de-obra, eram a continuaçăo das 
virtudes que os bandeirantes haviam possuído. Publicados na década de 20 , os estudos coincidiam com o período em que se encontravam no ápice a riqueza cafeeira e o predomínio paulista no país, tanto económica quanto politicamente.

$O$ desenvolvimento paulista pudera ter lugar graças aos imigrantes que, a partir de 1860 mais ou menos, haviam desembarcado na região, trazendo novos braços ao trabalho agrícola. No início do séc. XX, filhos e netos destes imigrantes eram já encontrados nas camadas econômicas elevadas, na intelectualidade, ou mesmo ocupando cargos políticos e na administração pública (19). Estudiosos que atualmente se têm voltado para a análise dessa época supōem que o aparecimento da figura do bandeirante, que ocorreu entăo, cobria todos os que habitavam o estado, fosse qual fosse a origem deles, permitindo assim uma integração dos imigrantes; operava-se uma aliança dos nacionais com os forasteiros, e uma nova raça surgia com as mesmas virtudes de arrojo, eficiência, amor ao progresso que marcara os mestiços dos antigos tempos, como havia mostrado Frei Gaspar da Madre de Deus ao elogiar os mamelucos (20).

Esta interpretação se baseia na noçāo de que o símbolo se caracterizaria por desempenhar funçōes eminentemente reforçadoras da solidariedade interna de um grupo ou de uma coletividade, perpetuando valores encarados como fundamentais para a manutenção da sociedade e de sua civilizaçăo. A definiçẫo da imagem do bandeirante pelos historiadores do início do sec. XX, num momento em que milhares de imigrantes e seus descendentes vinham se incorporar a sociedade paulista, teria sido um modo de intensificar os laços entre duas metades da mesma. A figura lendária reforçaria a coesão entre os naturais da regiấo e os alienígenas, envolvendo a todos na mesma consideraçăo de pioneiros, cada qual a seu modo.

Pode-se, todavia, levantar uma grande interrogação a estas interpretaçōes, com base numa série de observaçóes que, ao que se acredita, são aqui apresentadas pela primeira vez. Tanto mais que é nesse momento - década de 20 - que se cunhou o termo "bandeirante" com seu significado específico, como uma figura distinta da do paulista. Este último termo viu crescer entāo sua carga essencialmente geografica, marcando os que pertenciam a uma regiăo; o qualificativo "bandeirante" , por sua vez, surgiu com todo o peso de um significado histórico inconfundível. Năo esquecer a origem específica dos his-

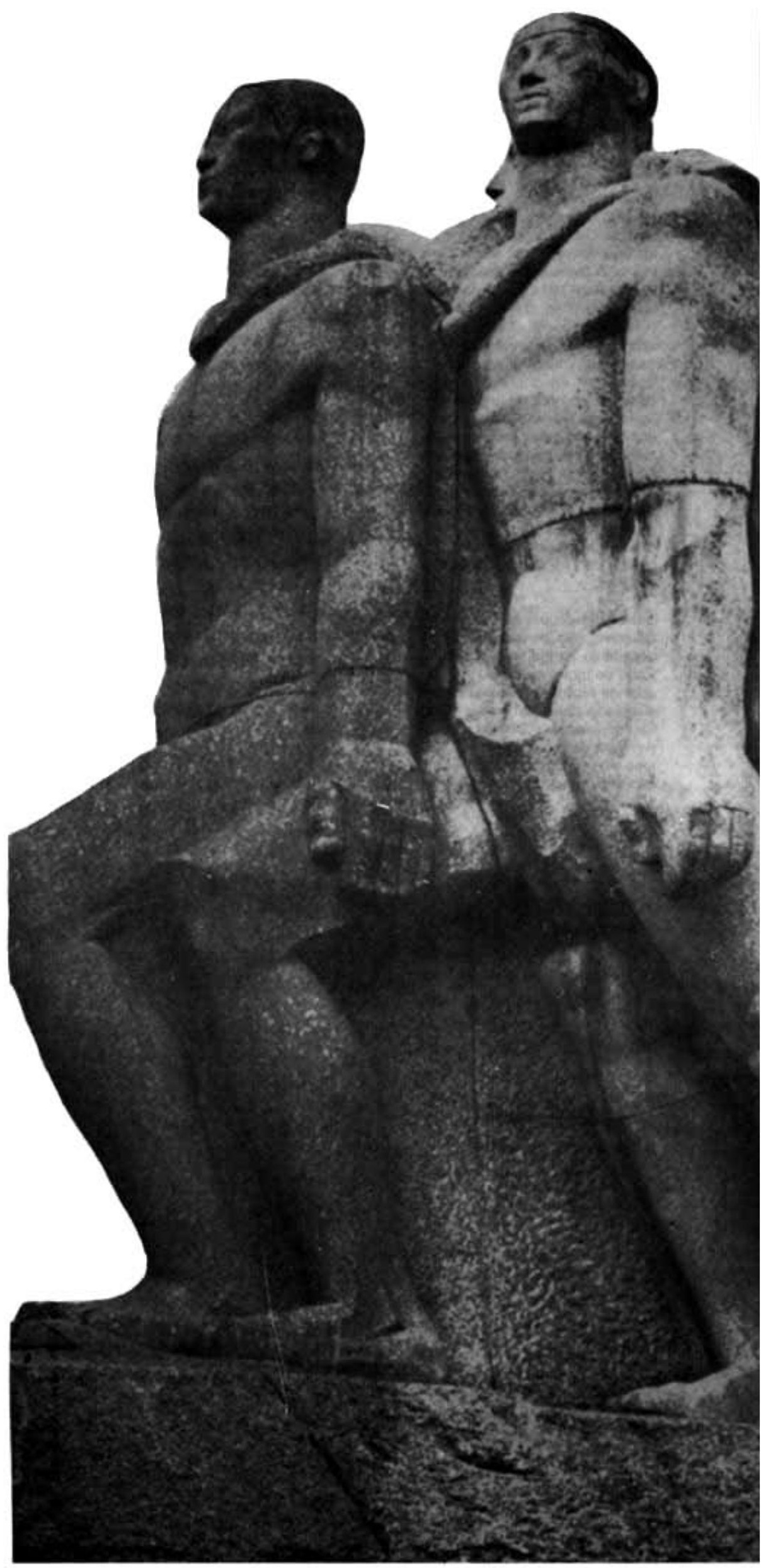


20 Além de Katia Maria Abud, que tealça o grande relevo alcançado peio bandeiranto como fator do coesâo, tamberm olotuam a mesma interpretaçá Joseph L Love. A Locomotiva: S. Paulo na Federa. çáo Brasileira (1889-1937). Rio de Janeiro, Paz e Terra, 1982: Maria Helena Capelatto, $O$ Movimento de 32: a Causa Paulista, Sio Pau lo, Brasilienso, 1981: Maria Ligia Prado, A Democracia llustrada: S Paulo, 1926-1934, Tese de Doutoramento, Dep. de Historia, Fa culdade de Filosofia, Letras a Ciências Humanas da Universidade de Sto Paulo, 1982, mimeografada. Katia Maria Abud principalmente encara o simbolo do bandeirante apenas em seu aspocto aglutina dor, como se esta fosse a única funçấo dosempenhada desde o inicio em Sáo Paulo. No entanto. sua própria andlise esta cheia de dados inconlundiveis sobre a fun cho segregadora desse simbolo. desde os tempos de Pedro Taques e de Frei Gaspar da Madre de Deus.

21 Esta expressâo, extremamente sig. níficativa, nâo pertence porém à decada de 20; ola fol cunhada no inicio do movimento de 1932 por José de Alcântara Machado, num discurso inflamado pronunciado na Faculdade de Direito. Inspira do nesse discurso, Martins Fontes logo em seguida utilizou a mesma expressto numa poesia que mar. cou época. toriadores, todos eles representantes das velhas famílias locais. O sentido profundo, subjacente a seus trabalhos, é a ligação estreita entre as qualidades dos bandeiran. tes e os predicados da elite paulista a que pertenciam. A filiação thes parecia indiscutivel, as virtudes da raça se haviam mantido atraves do tempo, consubstanciadas nas atividades pioneiras e resultando no engrandecimento da naçăo, de que se mostravam os mais legitimos motores.

Os imigrantes, seus filhos, seus netos eram paulistas; porém bandeirantes eram somente aqueles cujos avós, bisavós, tataravós e demais antecessores tinham traba. Ihado e pelejado no mesmo solo que agora abrigava a todos. O bandeirante en. quanto símbolo era criado repleto de um conteúdo discriminatório; separava, no interior do estado, uma coletividade antiga de outra coletividade de origem recente, valorizando altamente a primeira em detrimento da segunda. Os historiadores do sec. XX se mostravam, pois, muito próximos de seus antecessores, Pedro Taques e Frei Gaspar da Madre de Deus: como estes, seu intuito era traçar uma linha clara de separação entre "paulistas de $\mathbf{4 0 0}$ anos" (21) e forastciros.

Da mesma forma que no passado o simbólico paulista, agora o bandeirante, alem de uma discriminação, possuía um efeito compensatório: os imigrantes e seus filhos podiam se tornar milionários, pơdiam galgar altas posiçốes, porém não dispunham de uma riqueza primordial, a riqueza constituida pela glória dos antepassados. Năo alcançariam nunca um passado familiar e regional aureolado do esplendor de feitos extraordinários. Os alienigenas sem dúvida eram paulistas; porém não seriam jamais bandeirantes.

Os historiadores da década de 20 não foram os únicos a expressar a rejeição đos imigrantes; na literatura da época se inscreveu, também, a ojeriza contra o carca. mano, clara ou sutilmente: Macunaíma, herói que consubstancia essencialmente o ser brasileiro porque é ao mesmo tempo branco, africano e indígena, deixa suas longínquas florestas para vir a São Paulo, onde se engaja numa luta contra o gigante Pietro Pietra, cujo nome é significativo (22). Porém Mário de Andrade (1893-1945). o autor da citada epopéia, nâo foi o único a caricaturar o recém-chegado italiano; as aventuras e desventuras dos imigrantes (23) formam o cerne dos contos de Antonio de Alcântara Machado (1875-1941); e nessa mesma época o "poeta, barbiert $t$ giurnalista", sob o pseudônimo de Juó Bananére (1892-1933), imprime ironica-

Nesta página loto do

Monumento das Bandeiras, do escultor Victor Brecheret, inaugurado a 25 de janeiro de 1953, em comemoraçáo ao 399 • aniversário de Sáo Paulo e localizado na praça Armando de Salles Oliveira, no Ibirapuera; nas páginas anteriores. detalhes do Monumento

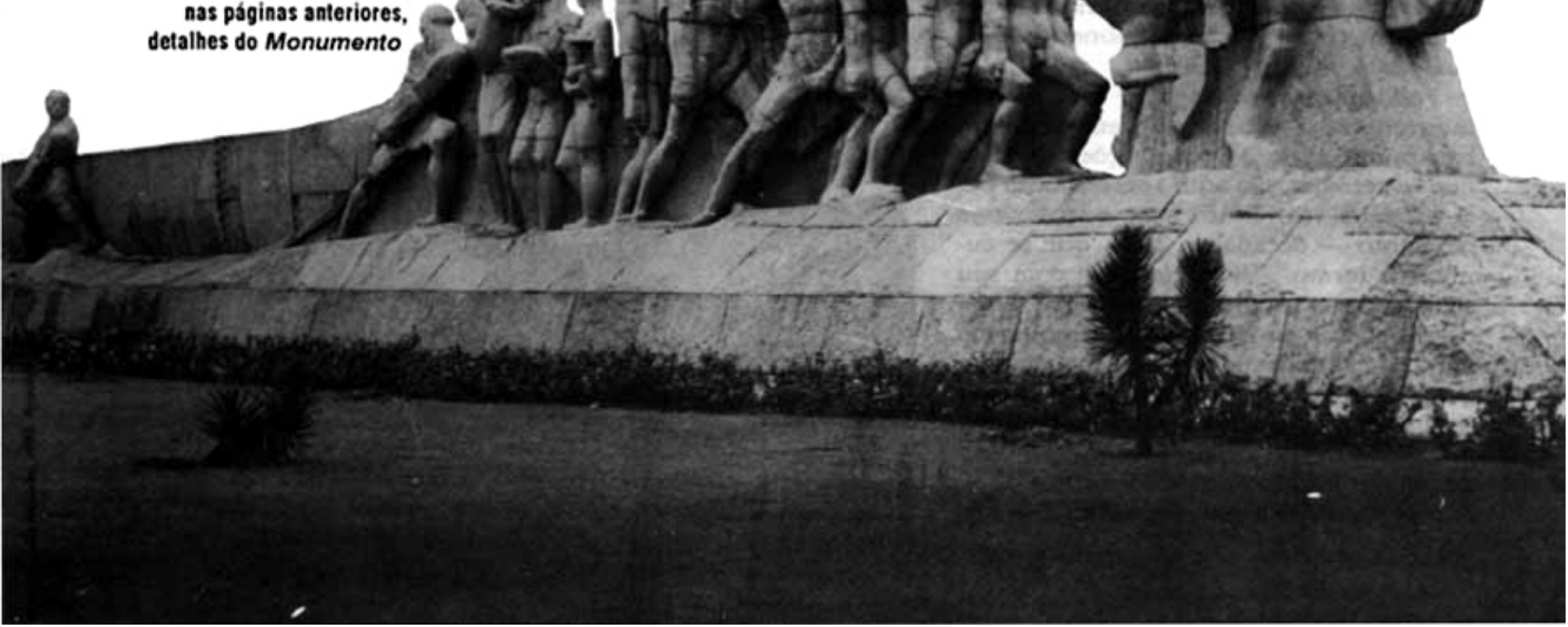


mente seu jornalzinho $U$ Abaxu Pique, imitando o linguajar arrevezado dos imigrantes (24). O tom de mofa aberto ou velado, a tolerância orgulhosa e condescendente dos escritores estavam também marcando claramente a separação entre as familias antigas e os forasteiros. Como no séc. XVIII, uma elite autóctone procurava manter sua posição hegemônica, fechando sua coletividade contra possíveis invasōes que a desfigurassem, ao mesmo tempo em que se consolava de suas perdas com a afirmação de um passado prestigioso, $\mathrm{c}$ com a desvalorização dos imigrantes. A figura do bandeirante $\mathbf{c}$ o relevo que lhe é dado então constituíam uma barreira oposta às possíveis ambições de integração dos forasteiros (25).

Assim, a figura do paulista até o início do séc. XX e, em seguida, a figura do bandeirante, quando analisados os contextos históricos e sociais em que surgiram e se firmaram, contém ambas, como elemento primordial, sua funçâo diferenciadora no interior de uma coletividade. No entanto, nos três momentos até agora analisados, nasceu o símbolo e se manteve circunscrito apenas ao âmbito de intelectuais interessados pela história de sua região, ou de escritores vivendo intensamente uma renovação literária - pequena minoria letrada $\mathrm{cm}$ meio à população cada vez mais avultada do estado; tanto mais que, mesmo nas camadas superiores, era modesta a quantidade dos que tomavam conhecimento do que era publicado pelo pequenis. simo grupo dos bomens de letras. A compreensão e a função das duas figuras lendárias, a do paulista a princípio, mais tarde substituida pela do bandeirante, pare. ciam destinadas a ficar por assim dizer encerradas nos livros. Uma circunstância inesperada veio modificar a situạ̧ão, projetando o símbolo do bandeirante para outros niveis sociais e modificando suas funçōes. Esta circunstância foi a Revoluçāo de $1932(26)$.

Tentativa controvertida, definida por uns como um movimento reacionário que buscava reinstalar uma dominação política paulista claramente destronada pela coligação do estado do extremo Sul com estados do Nordeste, encarada por outros como uma luta contra a ditadura que Getúlio Vargas pretendia instalar no país (o que só conseguiu em 1937), a Revolução de 32, eclodida em São Paulo a 9 de julho desse ano - luta armada contra as forças do governo central - durou até 9 de outubro, quando foi assinada a convenção para a cessação das hostilidades.

Para fazer face ao governo federal e às suas forças, era indispensável a uniâo de todos os componentes da coletividade paulista, de alto a baixo da escala social, com todas as etnias e nacionalidades. A camada hegemônica local lançou mão de todos os instrumentos para conseguir uma adesão a mais ampla possível que assegurasse participação a mais completa. A noção de " rạ̧a privilegiada dos paulistas" cobria agora todos os integrantes da coletividade; então bandeirante passou a ser sinônimo de paulista, unindo ao significado histórico o significado geográfico. Todos os que se esmeravam em servir o movimento deflagrado atestavam que eram descendentes, senão na origem, pelo menos no espírito e nas virtudes, dos antigos sertanistas.

Para que o símbolo ultrapassasse o âmbito intelectual restrito em que surgira, foram muito importantes os meios de comunicação de massa já existentes - jornais, revistas, cartazes, aos quais se somavam outros novos, como o alto-falante e o rádio, que alcançavam um público muito mais vasto (27). Três eram as emissoras paulistas existentes então: Record. Educadora e Cruzeiro; sem dúvida era relativamente reduzido o número dos que podiam possuir um aparelho receptor, porém, ligado a alto-falantes, concitavam na rua o povo à luta tanto no front quanto nas atividades de retaguarda, divulgavam amplamente slogans de apoio a causa paulista, difundiam discursos e apelos. O espirito bandeirante era constantemente invocado para reforçar o entusiasmo da populaçāo, lembrando que a iniciativa, a eficiência, a bravura que toda a coletividade estava demonstrando eram a prova da filiaçẩo ilustre. O Caçador de Esmeraldas, o Anhangüera eram invocados a todo instante como deuses lares que levariam os descendentes à vitória.

O grande sucesso alcançado então pelo símbolo foi patente; até hoje cle funciona como um sinal distintivo de todo aquele que trabalha pela grandeza do estado de São Paulo, independentemente de origem nacional, de etnia, de classe socioeconómica. Desde que contribua para que São Paulo exerça sua hegemonia dentro da nação brasileira, $e$ cle consagrado como um representante dos velhos scrtanistas. À sua característica de conservação das tradiçỏes, a imagem novamente incorporou designios voltados para o porvir: o bandeirante nảo era somente o descendente dos heróis de outrora, tornou-se principalmente aquele que, construindo o futuro, mostra-se digno dos ancestrais.
22 Mário de Andrade, Macunaima, Sâo Paulo, Livraria Martins Ed. nova ediçáo, 1944.

23 Antonio de Alcântara Machado. Brás, Bexiga e Barra Funda, 1927 e Laranja da China, 1928

24 Juó Bananére (Alexandre Ribeiro Marcondes Machado) alérn de imprimir "U Abaxu Pique", igualmente publicava poesias sarcásticas em que, na linguagem macarrônica dos imigrantes italianos. satirizava tambem a politica e a ti. toratura de sua época, sendo considerado um dos precursores da Somana de Arte Moderna. Rouniu em seguida as poosias num livrinho, La Divina Increnca, 1924.

25 As palavras do Pe. Feijó, citadas por José de Alcântara Machado. văo nesse sentido: "Eu me orgutho de ser de uma provincia célebre pelo seu distintivo de honra e pundonor, e onde se laz timbre de cumprir o que se promete" nificativo também que seja citado Foijo, um dos paladinos do paulis. tanismo. Observa ainda Alcântara Machado que realmente. no Sáo Paulo dos bandeirantes, muitissimos negócios se concluem e it. qûidam sem documento de qualquer espécie, aspecto om que -transparece aquella probidade intemerata, que á uma das feiçōes caracteristicas do velho espírito paulista.." (José de Alcăntara Machado. 1929. pp. 140-1)

$26 \mathrm{Em}$ meados dos anos 20 , uma parte da elite hegemónica paulista se havia separado do antigo PRP. pois reivindicava várias modifica. çós politicas, como por exemplo - volo secreto: por motivos óbvios, o velho partido desejava manter a forma de eleiçáo existen. to. que dava lugar a constantes a repetidas fraudes. Fundado pelos oposicionistas, um novo partido, o Partido Democrático (PD), apoiou a candidatura Getúlio Vargas à su cossáo de Washington Luiz, e tarmbern o movimento que depos a este úttimo. No entanto, uma vez ompossado Getúlio Vargas, náo tardaram os membros do PD a perderem suas ilusbes, diante da realidade inesperada: náo participavam do novo governo. nem mesmo em seu próprio estado. Assim, om 1932, juntamente com o PRP, exigiram uma constituiçáo que salvaguardasse a autonomia ameaçada dos estados. Decepcionados com a insensibilidade do governo para suas reivindicaçóes. juntos PD e PRP desencadearam a Revoluçáo de 1932

27 Este aspecto está muito bem analisado no livro de Matia Helena Capelatto, 1981. pp, 31 a 34 
28 Logo após o golpe de estado de 1937. o poeta, ensaista e historia dor Cassiano Ricardo (1895-1979) porta-voz de Getúlio Vargas em Sảo Paulo, tentou alargar ainda mais o simbolo do bandeirante. para que agisse como uma justifcativa do chamado Estado Novo Publicou entaao O Estado Novo e seu Sentido Bandeirante. Mas seus argumentos nâo alcançaram sucesso algum.

29 Seria importante verificar em que medida simbolos surgiriam nas camadas inferiores do pais, e sob que forma. Mais recente do que o bandeirante, um outro simbolo surgiu, que se generalizou e se tornou nacional - o cangaceiro $\mathrm{Na}$ forma pela qual é utilizado - a de paladino dos pobres e dos oprimidos - pareceria que teria surgido nas camadas inferiores. No entanto, uma primeira tentativa de análise de seu aparecimento mostra que este se teria dado também nas camadas superiores. $\mathrm{Na}$ década de 50 , o jornalista As sis Chateaubriand criou, num momento de irônica euforia, a Ordem do Cangaço, destinada a galardoar nacionais e estrangeiros que tivessem demonstrado, por meio de atos significativos, seu arnor ao Brasil. Apesar de sua ironia, a Ordern continha evidentes sentimentos nacionalistas diante do cosmopolitismo que avassalava cada vez mais a economia nacional. Pouco depois, a imagem tomou um colorido mais nitido, relacionado à luta contra as opressóes. Náo era mais somente o Brasil diante da voracidade estrangeira que era representado, mas também, num pais de enormes injus. tiças socioeconômicas, cristalizava a idéia do delensor dos fracos contra os fortes, do protetor dos explorados contra os desmandos dos grandes. Acrescente-se que o cangaceiro era peculiar ao Nordeste, isto é, a regiảo do pais que mais contrastava com as regiỏes abastadas do Sudeste e do Sul. O destino deste símbolo se dese. nhou, tambérn, ao nivel dos valo. res tradicionais, representativos da brasilidade essencial, uma vez que o cangaceiro pertencia àquela área do pais menos atingida pelas imigraçóes européias, asiáticas e outras. Um primeiro esboço desta análise Ioi feito por Maria Isaura Pereira de Queiroz. Os Cangaceiros, São Paulo, Livraria Duas Cidades, 1977. pp. 210 a 213: mais tarde loi reproduzido em História do Cangaço, da mesma autora, São Paulo, Global Ed. 1982
O êxito que assim cercou a figura do bandeirante parece reforçar a idéia de que sua virtude fundamental seria realmente a de fomentar a uniāo e a solidariedade entre grupos e camadas no interior de uma coletividade. O fato dela anteriormente se ter mantido restrita ao interior da camada hegemônica paulista somente, distinguindo-a da coletividade geral, seria apenas uma indicação de que não estava ainda sendo utilizada na totalidade de suas potencialidades. Agora, porém, a plenitude fora alcançada.

Todavia, observe-se que a coesão se operava apenas no interior da coletividade paulista. Transposto o limite desta, e em relação à sociedade global brasileira, o bandeirante tomava um colorido patente de discriminaçâo e não mais de união: distinguia, da totalidade nacional, os filhos do estado de São Paulo. Dando ênfase às virtudes bandeirantes, tacitamente comparava-as com os predicados dos naturais dos demais estados, numa tonalidade negativa para estes. O desenvolvimento econômico de São Paulo, o civismo de seus filhos lutando pelo benefício do país através da implantação de uma constituição, provavam que os naturais do estado formavam realmente uma raça privilegiada, diversa dos demais de outras regiōes, lídimos fatores do progresso nacional.

O insucesso do movimento intensificou a função diferenciadora do símbolo, despertando novo surto de separatismo, muito mais vigoroso e amplo do que o de fins do séc. XIX. Ele só se diluiu e apagou quando o Brasil foi forçado a participar da Segunda Guerra Mundial, diante do reforço do ser brasileiro.

Carregado de qualificaçōes exclusivamente locais, o símbolo não podia se tornar extensivo ao Brasil (28); ele represéntou cada vez mais, e somente, a gente do território em que se originara, diferenciando-a dos conterrâneos de outras plagas (29). Sua função discriminatória foi patente, indiscutível. No entanto, no interior da área paulista à qual permaneceu circunscrito, exerceu função contrária: unificadora, reforçando a solidariedade de grupos e de camadas. O orgulho de linhagem, que havia caracterizado o aparecimento do herói paulista no séc. XVIII, do herói bandeirante no séc. XX, chegara assim ao seu último avatar: alargou-se à amplitude de um orgutho regional, abarcando camadas sociais distintas, grupos de origem nacional $\mathbf{e}$ étnica diversas, separando-os em relação à sociedade global brasileira. $\mathrm{O}$ auto-engrandecimento produziu, como não podia deixar de ser, reação contrária por parte dos habitantes das demais regiōes. Assim, ambos os símbolos - paulista e bandeirante - expressaram e reforçaram, através do tempo, coesão e diferenciaçăo.

O símbolo tem sido considerado habitualmente em sociologia como fator eminente de coesão e solidariedade no interior de um grupo ou de uma sociedade, uma vez que encerra uma mensagem inteligível aos seus membros; a captação de um mesmo sentido por todos constituiria sólida e profunda base de união, pois mos-

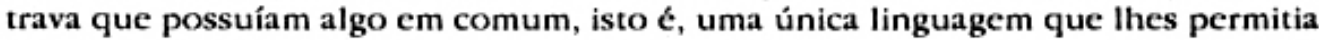
interpretaçāo idêntica do que era transmitido, determinando a unidade nas maneiras de ver, a semelhança nas maneiras de agir.

Certamente os componentes da coletividade paulista compreenderam sempre o que significavam o paulista e $\mathrm{em}$ seguida o bandeirante. Nos dois casos, a compreensão fora geral para os membros das camadas superiores, e separava quem era da velha estirpe, quem era de origem recente. Houve, pois, a princípio, em Sāo Paulo, duas formas diversas de compreender a mensagem; para uns, ela falava de união e de separação; para outros ela falava somente de separação. Existiam no interior da coletividade paulista partes que não se confundiam no plano do real, partes que, embora existentes ambas em todos os niveis sociais, se destacavam como diferentes; a compreensão que cada parte alcançava a respeito do símbolo seguia a linha de demarcação entre elas. Mais tarde, quando o bandeirante passou a agir como expressão de uniâo das diversas partes no interior da coletividade paulista, imediatamente tornou-se o sinal de demarcação entre esta e a sociedade global brasileira.

A importância dos símbolos não parece residir tanto em seu poder de coesão, $\mathrm{e}$ sim, ao contrário, em seu poder de delimitação de grupos, de coletividades, de sociedades, marcando com precisão os contornos deles. É devido às suas peculiaridades de elemento discriminador que o símbolo define seus predicados e constitui algo de vigoroso. Cada sociedade global no concerto das naçōes, cada coletividade dentro de uma sociedade global, cada grupo, cada família tem seus símbolos específicos, por meio dos quais se autoconhece em relação aos demais. Se os símbolos possuem em alto grau a peculiaridade de perpetuar os valores encarados como fundamentais para a continuidade de grupos $e$ de sociedades globais, enquanto enti- 
dades sociais, e devido às suas qualidades eminentemente delimitadoras.

Todavia, as virtudes discriminatórias ficam em geral escondidas pela ação interior que os símbolos desenvolvem, e que constituem um dos fatores importantes da continuidade das coletividades; desse modo, tornam-se aparentes suas características de promotores da coesão $\mathrm{e}$ da solidariedade e não se atenta para o fato de que, noutro ângulo, a ação é oposta e provavelmente mais importante. A inteligibilidade aparentemente geral do símbolo no interior de uma coletividade constitui eficiente máscara sob a qual disfarça sua ação diferenciadora; não deixa que se perceba a existência de uma linha de demarcação, delimitando formas diversas de seu significado, conforme se esteja deste ou daquele lado da linha.

A duplicidade, até mesmo a ambigüidade, seria a marca específica dos símbolos; isto $\dot{\epsilon}$, encerram eles pelo menos duas interpretações a um tempo, dependendo da situação em que se encontra aquele que o compreende. O símbolo é sempre inteligivel para as duas fraçōes de uma coletividade, mas cada uma o apanha em perspectiva diferente. A função mais ampla e profunda dele parece ser justamente a de permitir que fragmentos diferentes de um mesmo grupo, ou de uma mesma sociedade global, tenham através dele o conhecimento do eu e do outro, sua virtude primordial, ao que tudo indica, seria de concretizar a separaçāo entre eles, cristalizando-a de maneira a permitir o conhecimento recíproco.

Além desta característica, uma outra notada na formação da imagem do paulista, e em seguida na do bandeirante, é a dose de insatisfação e de frustrações da coletividade que a formula, ligadas à posição que julgam deveria ser a sua no sistema hierárquico; posiçāo que ou está ameaçada, ou não foi alcançada, ou se perdeu. $O$ símbolo aparece entâo como um mecanismo que ajuda a suportar injustiças e ofensas; intervém para suscitar, orientar e sustentar esforços no sentido de superar a situação desagradável ou penosa em que se encontram grupo ou coletividade esforços em desenvolver ações concretas para resgatar a iniqüidade, mas que simplesmente se esgotam na própria criação simbólica, levando simplesmente à sublimação. O personagem lendário pode tanto desencadear uma ação vigorosa para restabelecer direitos e privilégios, como constituir apenas uma forma de compensação ideal.

Finalmente, tanto o paulista como o bandeirante se originaram em camadas clevadas no interior de uma coletividade; a amplitude maior adquirida pelo símbolo do bandeirante deveu-se a circunstâncias específicas, e há quem avente a hipótese dele ter sido conscientemente manipulado nesse sentido pela elite local no momento conveniente. Seja como for, deu-se a ampliação, e o símbolo nāo regressou mais ao seu significado restrito anterior; isto é, o símbolo pode passar para as camadas inferiores, unindo-as entảo às superiores numa mesma coletividade, a qual se opôe agora a uma outra globalidade, a nacional. E foi determinado grupo, dentro da elite local - o grupo dos intelectuais -, que formulou o símbolo. Em que medida já existiria ele na elite, e os intelectuais somente lhe deram uma forma palpável através de seus textos? Esta parece a hipótese plausível, mas pesquisas específicas devem ser efetuadas para verificá-la $(30)$.

Hoje já se encontra plenamente estabelecido que toda coletividade, todo grupo, se expressa através de seu imaginário, isto é, do conjunto de imagens e de representaçôes míticas através do qual se autoconhece e se autoclassifica. Tais representaçôes não alcançam o mesmo grau de consciência em todos os membros do grupo e em todos os momentos, mas estâa presentes na totalidade deles, pelo menos em seu inconsciente, constituindo um dos motores de delimitação no interior de um espaço social. Entre as partes que compõem um grupo ou uma coletividade, ou nos grupos e coletividades em relação à sociedade global, a delimitação traçada pelas representações, que se concretizam em símbolos, ajuda a dar a conhecer aos indivíduos o lugar que acreditam ser o seu e a se distinguir dos demais; a formular aquilo que aceitam e aquilo que rejeitam. Numa mesma coletividade, conforme suas demarcaçôes internas, as figuras imaginárias fazem aparecer coesôes mas também contradiçōes e divisōes. Oriundas de um processo cognitivo a mais das vezes inconscieate, as figuras imaginárias se constroem apoiadas em estímulos opostos, em respostas contrárias, que agem simultaneamente no interior dos grupos, das coletividades, das sociedades globais. Promovem um autoconhecimento e uma auto-avaliação aparentemente imaginários; na verdade estāo possibilitando o reconhecimento e a avaliação da posição de um grupo em relação a outro. E esta parece ser sua qualidade essencial.
30 Este utanismo paulista deu lugar a inúmeras poessias, principalmente durante a Revoluçäo de 1932 e os anos imediatamente posteriores. Guilherme de Almeida (18901969), o "Principe dos Poetas". tove grande número de seus versos voltados para a glorificaçảo do bandeirante, entre os quais sobressai "Bandeira Paulista". Porém as estroles que melhor exprimem a paixáo paulista sem dúvida sấo de José Martins Fontes (1884-1937). médico de Santos, com a poesia "Todos Cantam sua Terra": "Paulista eu sou há quatrocentos anos!/lmortal, indomável, infinita/Dos mortos de que venho ressuscita/A alma dos Bandeirantes sobre-humanos.//Tenho orgulho dos nossos altiplanos $/ \mathrm{Te}$ nho a paikảo da gleba circunscrita./Quero morrer ouvindo a voz bendita/Dos pausados cantares paulistanos. $/ /$ De minha terra, para minha terra/Tenho vivido/Meu amor encerra/A adoração de tudo quanto $b$ nosso.//Por ela vivo num perpétuo enlevo/E incapaz de servi-la quanto devo,/Quero ao menos amá-la quanto posso!" A poesia foi composta em jultho de 1932. depois que Martins Fontes ouviu um candente discurso de José de Alcântara Machado (um dos gran. des oradores do Movimento), em que o prócer exclamara: "Paulista eu sou há quatrocentos anos..." Justamente nesse ano eram comemorados os 400 anos da chegada de Martim Alonso de Souza a S. Vicente, trazendo os primeiros colonos que povoariam a capitania do mesmo nome, que mais tarde passou a se chamar São Paulo; de velha estirpe paulista, José de Alcântara Machado podia afirmar "seus" 400 anos de per. manência na terra. $O$ discurso foi prolerido por ele no dia de sua posse na Academia Brasileira de Letras. O primeiro es dois últi. mos versos, Martins Fontes tomou. os ao inicio a a fim do mesmo. 